ARTICLE

https://doi.org/10.1057/s41599-019-0301-2

\title{
Faith-based organizations in Turkey as indirect political patronage tools
}

\author{
Sakine Arslan Köse ${ }^{1}$
}

\begin{abstract}
Social assistance is one of the most effective tools for poverty alleviation. However, it can also serve as a means of managing and silencing the poor in regard to the difficulties imposed by the system in which they live. Recognizing the voting potential of the poor in Turkey, political parties have frequently implemented social assistance and political patronage. Faith-based organizations (FBOs) also operate in the field of social assistance and are supported by the government. There have been people and organizations that have had an intermediary role in Turkey since the era of the Ottoman Empire. In this regard, the missing element in the existing literature is an examination of the intermediary role played by social assistance in political patronage. This study coins the term indirect political patronage (IPP) to address the role of FBOs that work to consolidate the government in Turkey. The significance of this paper is that it brings together a discussion on the FBOs (religion) and political patronage implementation in social assistance programmes (poverty) to understand and examine the role played by FBOs by using the concept of IPP. To scrutinize these roles, the examination of the relationship between the state and FBOs in social assistance programmes is of key importance. The relationship can be observed in several spheres, such as governmental incentives as dependency indicators. The relationship also presents a periodization of $\mathrm{FBOs}$ regarding their visibility in the public space and the roles that they play in domestic politics, which are both closely related to their performance as actors of IPP. Furthermore, the classification that this study offers through this periodization, noninstitutionalized and institutionalized, provides an organizational analysis of the evolution of FBOs in terms of building necessary skills and achieving a certain level of establishment. In this study, conceptual arguments, field studies, in-depth interviews, and statistical data on social assistance were utilized. FBOs that are affiliated with a religious community, enjoy public benefit status and operate in the districts that are locally run by Justice and Development Party (JDP) municipalities were selected for the purposes of measuring and evaluating their roles in IPP.
\end{abstract}

\footnotetext{
${ }^{1}$ Nișantașı University, Istanbul, Turkey. Correspondence and requests for materials should be addressed to S.A.K. (email: kosemsakine@gmail.com)
} 


\section{Introduction}

aith-based organizations (FBOs), as religiously motivated welfare initiatives, have become significant actors in the social policies of countries, particularly since the beginning of the neo-liberal age. Acting as nongovernmental organizations (NGOs), they have contributed to social assistance in the struggle against poverty in line with the social policies of countries. In Turkey, the significance and visibility of these organizations increased after the devastating earthquake of Adapazari in 1999. In the following years, a proliferation of FBOs has been observed, which further increased with the ascent of the Justice and Development Party (JDP) to government in 2002. This increase, however, took place as social assistance became an instrument of patronage to consolidate the JDP government. In the Turkish experience, political patronage has been mostly discussed under neo-liberal practices (Heper and Keyman, 2006; Çelik, 2010; Koray and Çelik, 2015; Yıldırım, 2013) with an implication of consolidating the government using state resources. In line with the existing literature, my field research (Arslan Köse, 2018) indicates that the election victories of the JDP have been broadly discussed in the context of social assistance practices (Buğra, 2011; Koray and Çelik, 2015, Yıldırım, 2013). During the JDP rule, the social state heritage of Turkey has leaned toward a social aid state, with a significant increase in social assistance, which eventually creates dependent people regardless of its original objective (Arslan Köse, 2018; Koray and Çelik, 2015). The objective, perhaps, does not confine itself to securing a significant rate of votes in the elections and involves creating dependency on and loyalty to the JDP government. In this respect, the FBOs have performed as social assistance actors in domestic politics by creating dependency on and cultivating loyalty to the JDP government.

The mediatory role of social policy actors in political patronage has been mostly discussed in the context of indirect political patronage (IPP). The primary contribution of this study comes through offering a new way of thinking about the correlation between FBOs and the JDP government in terms of IPP, which mainly involves many faith-based initiatives, the poor, and the government. This approach offers an original concept, the IPP, to frame the activities that create dependency/loyalty on the government through the distribution of social assistance. This approach also presents a periodization of FBOs regarding their visibility in the public space and the roles that they play in domestic politics, which are both closely related to their performance as IPP actors. Despite lacking clear-cut demarcations, periodization is analytically useful as it facilitates the comprehension of the shifting roles of FBOs in domestic politics. Furthermore, the classification that this study offers through this periodization as noninstitutionalized and institutionalized provides is an organizational analysis of the evolution of FBOs in terms of building the necessary skills and acquiring a certain level of establishment.

Conceptual arguments, field studies, in-depth interviews, and statistical data on social assistance were utilized in this study. In the design of the research, FBOs that are affiliated with a religious community, enjoy public benefit status and operate in the districts that are locally run by the JDP municipalities, were selected for the purposes of measuring and evaluating their roles in IPP (Tables 1 and 2).

The main objective of this study was to examine the political role played by the mediatory organizations to consolidate the government through the practices of IPP. Such mediatory roles have historically been played in Turkey by local notables such as eşraf and ayan in Ottoman times and neighborhood associations in the Republican era (Ayata, 1994). This study examines the role through the concept of IPP. The study uses a Gramscian perspective of the intermediary role of civil society between the state and the public to explore the conservative policies of the JDP government. As pointed out by Gramsci (1999), these FBOs act as the forces of status quo rather than socio-political change. The JDP government heavily utilizes conservative values and focuses on the past to construct the present. The Gramscian interpretation of "consent" can be perceived through "dependency" and "loyalty." Conservative governments tend to create the present in the image of the past and to create political content out of religious and nationalistic sentiments. In this regard, the utilization of FBOs, as religiously inspired and motivated groups, does not stand out as a surprising element.

This paper is organized as follows. The first section explores the main concepts, such as FBOs, political patronage, and IPP. The second section addresses the indicators of political patronage and emerging mediatory actors in it. The third section focuses on the fieldwork methodology and offers a structured correlation between the JDP government and the proliferation of FBOs. The concluding section presents how IPP has been practised through FBOs during the JDP government and offers a new approach to understanding the election victories of the JDP government.

On the concepts of faith-based organizations and political patronage. FBOs constitute a broad group of diverse organizations that distribute social/humanitarian aid with a religious identity and motivation. Faith plays the central role in both gaining donations and running organizations. While there is no consensus on the definition of FBOs, some characteristics involve "affiliation with a religious body, a mission statement with explicit reference to religious values, financial support from religious sources, choice of programs, and intended outcomes" (Ferris, 2005; Sider and Unruh, 2004). These organizations reflect a clear influence of faith in all the organizational stages, that is, from the very establishment of the institutions to the campaigns that they run and the benefits that they provide.

The FBOs in Islamic countries generate motivations out of religious tenets pertaining to engaging in social solidarity and obtaining the holy consent of God. In Islam, as in most religions, philanthropists are promised great returns both in this world and the hereafter. The practice of almsgiving (zakat) through which the wealthy donate one fortieth of their wealth to the needy goes through these FBOs to reach out to the poor people. The FBOs have extensive donation resources derived from religious motivations that are either nonexistent or less emphasized in secular organizations. These sources are primarily the "zakat" (almsgiving), "sadaka" (donation), and "kurban" (sacrifice), and the majority of Turkish society performs at least one of them. As Jawad and Cakar (2010: p. 665) explain, "one of the most prominent Islamic institutions of welfare is zakat $(2.5 \%$ tax on assets) which has historically acted as an important form of social welfare provision through income redistribution and socioeconomic development." Zakat is based on the notion of community solidarity. Sadaqa is another form of charitable donation recommended by Islam, which mostly accounts for smaller volumes. The animal sacrifice during the eid, which is called kurban in Turkish, is also a practice of social solidarity. The meat of sacrificed animals is distributed to the domestic and international poor. These sources constitute the major types of donations that enable the existence of FBOs in Turkey. Religion, with its practical imperatives of moral values and social solidarity, which, more importantly, causes it to become a coherent and meaningful whole, can reach a broader audience and exercise significant persuasion. As Wutnow explains (1998: p. 308), religion, as a force and influence, binds people to one another and 
Table 1 JDP's vote (percentage) in the 2014 and 2019 local elections and the active FBOs

\begin{tabular}{|c|c|c|c|c|c|c|c|c|c|}
\hline District & $\begin{array}{l}\text { Municipal } \\
\text { council } \\
\text { election } 2014\end{array}$ & $\begin{array}{l}\text { Municipal } \\
\text { council } \\
\text { election } 2019\end{array}$ & $\begin{array}{l}\text { JDP } \\
\text { municipality }\end{array}$ & Besir assoc. & Hayder assoc. & Valide assoc. & Yardımeli assoc. & $\begin{array}{l}\text { Deniz } \\
\text { Feneri assoc. }\end{array}$ & $\begin{array}{l}\text { IHH } \\
\text { Foundation }\end{array}$ \\
\hline Esenler & 62.3 & 65.48 & $x$ & & & $x$ & & & \\
\hline Fatih & 48.6 & 53.03 & $x$ & & $x$ & & & & $x$ \\
\hline Küçükçekmece & 41.9 & 45.22 & $x$ & & & & $x$ & & \\
\hline Pendik & 52.9 & 54.76 & $x$ & $x$ & & & & & \\
\hline Ümraniye & 49.5 & 54.57 & $x$ & & & & & $x$ & \\
\hline
\end{tabular}

Table 2 FBOs according to the affiliated communities

\begin{tabular}{|c|c|c|c|c|}
\hline Name of FBO & Affiliated community & Year of establishment & $\begin{array}{l}\text { Year of public } \\
\text { interest status }\end{array}$ & Center/Branch districts \\
\hline $\begin{array}{l}\text { Beșir Association of Solidarity and } \\
\text { Assistance }\end{array}$ & $\begin{array}{l}\text { Menzil Adıyaman } \\
\text { Community }\end{array}$ & & 2013 & Pendik \\
\hline $\begin{array}{l}\text { Hoca Ahmet Yesevi Association of } \\
\text { Solidarity and Assistance }\end{array}$ & $\begin{array}{l}\text { Cübbeli Ahmet } \\
\text { Community }\end{array}$ & 2005 & 2015 & Fatih \\
\hline Valide Humanitarian Aid Association & & 2010 & 2014 & Esenler \\
\hline $\begin{array}{l}\text { Yardımeli International Humanitarian } \\
\text { Aid Association }\end{array}$ & $\begin{array}{l}\text { Mustafa İslamoğlu } \\
\text { Community }\end{array}$ & 2007 & 2012 & Küçükçekmece \\
\hline Deniz Feneri & İskenderpașa Community & 1998 & & Zeytinburnu, Ümraniye \\
\hline $\mathrm{iHH}$ Humanitarian Relief Foundation & National Outlook & 1995 & 2011 & Fatih, Ümraniye \\
\hline
\end{tabular}

creates multilateral dependencies among them. The aid of the rich for the poor, then, is made possible as a result of the connection established by religion, and FBOs run their activities on the grounds constructed by this connection.

Since the late 20th century, the number of FBOs that engage in humanitarian aid activities has increased. Sider and Unhur (2004) classify FBOs into the following five categories in terms of their relation to a faith system: faith-permeated, faith-centered, faithaffiliated, and faith-backgrounded organizations and faith-secular partnerships (Swart et al., 2010: p. 79). In this study, the faithbackgrounded organizations, as actors in the Turkish social assistance system, are explained by the following: "faith is part of the historical inception of the organizations, and some members of staff may be motivated by their religion" (Jawad, 2012: p. 75). In addition, "they appear and act like secular organizations, ... but faith is not a criterion for selection. (Therefore), the programs of these organizations contain no specifically religious elements" (Swart et al., 2010: p. 79). Clarke also offers a categorization that involves five types of organizations: faith-based representative organizations or apex bodies, faith-based charitable or development organizations, faith-based socio-political organizations, faith-based missionary organizations, and faith-based radical, illegal, or terrorist organizations. According to Clarke's classification, this study focuses on faith-based charitable or development organizations "which mobilize the faithful in support of the poor and other social groups, and which fund or manage programs which tackle poverty and social exclusion" (Clarke, 2008: p. 25).

The field study that I conducted reveals that the FBOs that engage in social assistance activities can be described as the organizations that are "mostly founded by a religious community with a religious motivation." These organizations try to act as the secular NGOs in terms of institutional establishment, yet most of their donors act with religious motivation. These FBOs obtain an overwhelming majority of their funding from religious tools such as sadaka, zakat, and kurban. These organizations harmonize themselves with government policies in terms of the field they operate in and the type of activities that they engage in.
Recognizing the poor and understanding political patronage. In welfare regimes, approaches to social policies have a variety that spans rights-based to benevolence/gratitude-based perspectives. Benevolence/gratitude-based social assistance or, to be more precise, the intense use of this policy is commonly seen in countries where democratic development is not complete and is immature in terms of political culture, income equality, and public access to education (Koray and Çelik, 2015). In such countries, the core issues of social assistance are dependence on the government and the existence of political patronage (Arslan Köse, 2018).

To begin, clientelism should be discussed in terms of broadening and, therefore, becoming the main grounds for political patronage. Both clientelism and patronage are the concepts that are used to explain buying votes and mobilizing people as a practical political tool. The concepts are mostly used in an overlapping manner in political analysis and therefore suffer from a lack of consensus in the literature (Stokes, 2007: p. 603). Lande's definition contains fundamental elements of the term: "it is a vertical dyadic alliance... between two persons of unequal status, power, or resources each of whom finds it useful to have as an ally someone superior or inferior to himself" (Landé, 1977). One of the two elements in this definition is "dyadic," which requires face-to-face communication. The alliance that "emphasizes the repeated-and sustainable-character" of the network is the other element of the definition. Stokes acknowledges the structural body of clientelism and patronage between the patron and client as unequal actors such as slave and master, serf and lord, worker and manager, and voter and party leader. Both sides of the relationship are based on voluntary values just as its exploitative character is (Stokes, 2007: pp. 606 and 608). The definition indicates that the unequal status of actors in dyadic sustainable relationships have a mutual interest. Scott emphasizes the nature of the relationship, which is an "instrumental friendship in which an individual of higher socio-economic status (patron) uses his own influence and resources to provide protection or benefits, or both, for a person of lower status (client) who, for his part, 
reciprocates by offering general support and assistance, including personal services, to the patron." Scott focuses on the support or loyalty of people that the government expects in exchange for the redistribution of public resources (Scott, 1972: p. 92). Clientelism is described as "the proffering of material goods in return for electoral support, where the criterion of distribution that the patron uses is simply: did you (will you) support me?" (Stokes, 2007: p. 606). In this concept, support refers to buying votes and securing electoral mobilization. In other words, clientelism is an electoral tool not only for the government but also for the opposition parties. In conclusion, political clientelism refers to party behavior to access and maintain political power.

Political patronage is a complex and controversial term with different dimensions. The term patronage is used to explain diverse concepts, including corruption (Freedman, 1994) or the provision of public sector jobs (Robinson and Verdier, 2013), which is not the concern of this paper. Weingrod uses the terms in the popular meaning and defines it as "the ways in which party politicians distribute public jobs or special favors in exchange for electoral support" (Weingrod 1968: p. 379). Stokes' definition of political patronage centers around "the proffering of public resources (most typically, public employment, in this research distributing social assistance) by office holders in return for electoral support" (Stokes, 2007: p. 607).

Social and political life influences the practices of political patronage, which changes from one country to another or from one period to another in the same country (see Weingrod, 1968; Scott, 1972; Sayar1, 1977; Ayata, 1994; Freedman, 1994; Wantchekon, 2003; Stokes, 2007; Brun, 2014). The turning point in the studies of patronage was the work of Moynihan and Wilson (1964) in the United States, which emphasized the recognition of minority groups and their provision of opportunities during the administration of Governor W. Averell Harriman between 1955 and 1959 to consolidate power. Recognizing certain groups that may be religious, racial, national, ethnic, or poor was seen as a principal function of patronage. The first step was to acknowledge the minority groups and then to give them prestige, power, or other benefits to secure their votes (Moynihan and Wilson, 1964: p. 296). In particular, in the new democracies, where uncertainty in the political realm is high, parties may use ethnicity to identify and mobilize voters belonging to ethnic categories, as emphasized by Chandra (2004) and Birnir (2009). In the African context, clientelism is often suggested to have an ethnic dimension, and most African studies present examples of ethnic voting (Kudamatsu, 2009; Burgess et al., 2015; Franck and Rainer, 2012; Isaksson and Bigsten, 2014). On the other hand, Latin America (Nichter, 2010) and Southern Europe (including Turkey) (Ferrera, 1996; Gough, 1996) are mostly characterized by clientelism that builds on exchanging favors through social policy.

The studies in the Turkish literature refer to the democratization process as the second wave of political patronage (Stokes, 2007: p. 609). It is necessary to acknowledge that there is no consensus regarding the definitions and content of the concepts. In some studies on the Turkish case, patronage was linked to nepotism, that is, being "someone's man" (Kurtoğlu, 2012: p. 144). Saribay (1992: 124) claims that patronage is a significant tool for political parties in election campaigns in Turkey, as it is in other developing countries. Sunar examines the issue in the context of Turkish political history at a point where it unites with the concept of populism. Patronage, according to Sunar, was a weapon used to persuade the public in favor of the Democrat Party (DP), which was the first party to control the government after democratic elections. The ultimate purpose was "to bind" the people to the party. In other words, the desired result was "loyalty" (Sunar, 1990: p. 750). In her seminal work on clientelism/patronage in Turkish political life, Ayata expands the issue beyond the practices of DP. The study covers a long period that starts from Ottoman times and ends in the 1980s with the practices of the Motherland Party (MP) government. During the period of the MP government, political clientelism/patronage was established in government practices through social assistance policies and became a tool for buying votes (Ayata, 1994: pp. $50-58)$. Kalaycioğlu is among the scholars who see political patronage as a common practice of democratic regimes in Turkey. According to him, "democratic regime as practiced in Turkey puts heavy emphasis on clientelist networks, primordial favoritism, and nepotism." Ultimately, Kalaycioğlu highlights the role of patronage as a "central or core dimension of democratic practice" (Kalaycıoğlu, 2001: p. 66). Competition in political life, that is, the advent of a democratic regime, opened the door for patronage and made it stronger. Similar to Kalaycıoğlu's (2001) statement, Heper and Keyman (2006: pp. 259 and 261) also see political patronage as a strategy within the boundaries of democracy. Sayarı, whose work is based on that of Ayata, highlights the same periods, and examining his historic classification suggests that the JDP is in a clientelist relationship with the urban poor (Sayar1, 2011: p. 91).

In recent studies, the increase in the amount of social assistance distributed by the state and NGOs and the fact that social assistance has turned into a tool of political patronage during the JDP rule are frequently argued. Another observation regarding this period is the proliferation of philanthropic language in the context of social assistance (Çelik, 2010; Koray and Çelik, 2015; Ylldırım, 2013), which facilitated political patronage through social policies.

Early symptoms of political patronage and emerging mediatory actors in Turkey. It would be fair to start a discussion of the practices of political patronage in Turkey with the transition to democracy; however, to identify the position of social aid in religious practices and the presence of intermediary institutions, the examination must begin from the Ottoman Empire in the late 19th century. During Ottoman times, the family and the relatives were the primary subjects and objects of social solidarity in the empire. Religiously motivated actions such as almsgiving, eid alfitr, and sacrifice were major social assistance practices (Makal, 1997: p. 213). In addition to this kinship-based informal social assistance, foundations played similar roles through their wellestablished institutional structures. Prominent examples of these were the Darülaceze, Darüleytam, and Hilal-i Ahmer Associations in the late Ottoman era (Baytal, 2012: p. 16). Guild and neighborhood associations functioned as a kind of social security (Ginio, 2003: p. 169). This approach was not the same as the social policy that has been applied in western countries due to Turkey's late modernization and the absence of a nascent working class (Koray, 2012: p. 115). Land ownership, the state's regular intervention in markets, and the economic structure did not encourage rapid industrialization and capital accumulation. The land, essentially, belonged to the state, and this did not allow industry to emerge (Talas, 1980: p. 323; Boratav, 2003: p. 36; Kalfa 2015: p. 70). In the Ottoman Empire, the state avoided close and face-to-face relations with the people who mostly lived in villages and were less educated. Notables (ayan) were mostly used as mediators between the central administration of the empire and the periphery, and the state communicated with the public through them. Small town merchants (eşraf) and landowners (ağa) replaced "ayan" as mediators in relationship in the early 20th century (Lewis, 1968: p. 441).

The early symptoms of IPP emerged through this system of intermediaries in the Ottoman era. The first decades of the Republican era (1923-1950) witnessed single-party rule, and the 
Republican People's Party (RPP) had no competitor. Therefore, the state did not feel obliged to provide social benefits to society that would imply the presence of patronage relations (Ayata, 1994: p. 50; Sayar1, 2011: p. 6). However, this period can be identified as the initial stage of clientelism in Turkey (Ayata, 1994) when the governing RPP connected only with notables at the local level. During this period, the majority of the population $(80 \%)$ lived in rural areas, and the urban population experienced poor economic conditions (Kalfa, 2015: p. 84). The rural population lived cut-off from the center, and their relations with the state were limited to performing military service and paying taxes. The only way to integrate the center with the periphery was to use the existing notables who in time became representatives in the parliament and were used by the state as a link to reach out to the rural populations (Mardin, 1973: pp. 172-178). Therefore, the needy did not have the kind of relationship with the state that allowed them to ask for assistance.

As the multiparty system started in 1946, the newly founded DP, which was the rival to the RPP, focused on face-to-face communication to gain the votes of mostly urban people in the election period. This was the first instance of such communication in Turkish politics and was, therefore, the beginning of political patronage (Ayata, 1994: pp. 55-57). The patronage relations began to appear to be an effective and functional strategy in Turkish political life (Kalaycioğlu, 2001: pp. 62 and 63). The rapid urbanization and proliferation of the poor created fertile grounds for party patronage. Political parties recognized the fertile new population that migrated from Anatolia to large cities such as Istanbul as an opportunity to buy loyalty to their parties. In the Justice Party (AP) period, migration to large cities created new social groups and organizations such as neighborhood associations, trade unions, and ethnic associations. Conducting the relations between the parties and the broader society, these organizations acted as the new mediators in the patronage system. The AP used these organizations to build IPP during the 1960s (Ayata, 1994: p. 55). Kalaycıŏlu (2001: p. 63) emphasizes other IPP groups such as solidarity groups and religious brotherhoods at the periphery. These intermediary structures that played the IPP role started to function in this period. Later, these groups would evolve into the FBOs with the advent of the neo-liberal period.

In the neo-liberal period, bitter economic conditions created a new disenchanted segment in society. Social assistance programmes were deemed necessary to win the support and loyalty of this segment. The lower and middle classes were turned into an important source of votes via the dependency created through social assistance practices by the government. Regarding the volume of social assistance during the MP period, Ahmad (1993: p. 191) argues that it was unprecedented. There were special funds for virtually anything, from parking lot issues to helping the poor (fakir fukara fonu), which was publicly known as the "fakfuk fon." Thus, the MP government did not reduce poverty but dealt with poor people (Ayata, 1994: p. 58; Karatay, 2010: p. 22). In the following years, the green card with its many healthcare benefits was put into practice and made its impact. The funds and the green card turned the social state into a conservative benevolence state and consolidated poverty in social and economic life (Bora, 2009: p. 1).

The formation of FBOs in this period signifies the popularity and importance attributed to religious practices and civil society. In the years of the MP government (1983-1991), FBOs were not visible in the public space as organizations formalized and approved by the state. With the advent of the JDP in 2002, these religious groups won formal recognition through legal amendments. It would be fair to argue that the foundations of the political patronage practices of the AKP government were laid during the MP government with a strong fund system to manage poor people in neo-liberal settings.

The proliferation of FBOs and IPP during the JDP government period. Having won five successive general elections, the JDP has been in power for over 17 years, which is an unprecedented span of time in Turkish politics since the transition to democracy. Most of the founding elite came from the National Outlook tradition, whose Welfare Party (WP) almost acted as a social assistance network before the elections in 1994. The large party base was organized to provide all sorts of services for those in need, including health services and the distribution of food, clothes, and coal. Going door to door, the network established a substantial amount of one-to-one communication with voters (Heper, 1997: p. 36). Inheriting this network from the WP facilitated the establishment of FBOs during the JDP period (Buğra and Keyder, 2006: p. 226). In this period, the FBOs transformed from fluid and community-based semiofficial initiatives to official entities. The official status brought state support, growth, and propaganda. These entities were mentioned under different names, Islamist, conservative (Ocaklı, 2017; Kaya, 2015; Kalaycioğlu, 2007; Çarkoğlu and Kalaycıŏlu, 2009), populist (Dinç̧̧ahin, 2012; Yıldırım, 2013), authoritarian, hegemonic (Keyman, 2010), and philanthropist, under the shadow of clientelism (Koray and Çelik, 2015; Köse and Bahçe, 2012; Bakirezer and Demirer, 2013; Çelik, 2007). In this respect, "understanding the philanthropic state" appears to be an important concept that descended from "the papa state" (Heper, 2015) and was furthered during the JDP period.

The social assistance programme that is based on the benevolence approach creates gratitude among the people who are provided with aid from state resources. The programme is determined by the mechanisms of the ruling party, and some of it is not legally regulated (Ylldırım, 2013: p. 102). With such a practice of social assistance, poverty is neither eradicated nor reduced. Instead, by creating dependent citizens, poverty is managed as desired (Koray and Çelik, 2015: pp. 30 and 38). Election periods witness significant increases in assistance. Three million families and $\sim 13$ million individuals benefit from government social assistance (Milliyet, 2016). Due to criticism about the nature and volume of social assistance, the JDP ceased to share information about this with the public. Providing public assistance through municipalities and other public organs, the JDP also incentivizes the activities of FBOs.

Indirect political patronage. In the social assistance relevant to political patronage, some intermediary actors were mentioned above, such as merchants, landowners, neighborhood associations, trade unions, and ethnic associations (Ayata, 1994). FBOs played a similar role between the state and the public and, therefore, were utilized by the state in a way that can be described as IPP. Indirectness is related to the lack of transparency by the state and a lack of autonomy by civil society in the JDP period (Koray and Çelik, 2015: p. 21), where the government provided benefits and state resources to FBOs that had similar missions and worldviews as itself.

Rosenblum and Lesch (2011: pp. 286, 291, and 292) describe these benefits as "assigning and also providing the elements of legal status, rights, and responsibilities which makes it a material patron, purchaser, funder, and partner in the presumptively beneficial activities." Antonio Gramsci (1971: p. 245) scrutinizes the ideological relationship between the state and civil society, which, by definition, includes NGOs. According to Gramsci, civil society is used by governments to create consent and establish hegemony. The author draws attention to the fact that the state 
and civil society share the same goals. The state may use civil society for social transformation or as an "apparatus" (Althusser, 2014) to realize its policies. To realize the transformation or establish hegemony, the continuity of the state/government should be maintained. In such a situation, the civil society-state relationship can be described within the scope of hegemony, transformation, or dependence on assistance or political patronage, which is the subject of this study. In any case, civil society is not independent of the state but rather depends on it via the provision of public resources and legal regulations. Although an "autonomous" status, as Diamond (1994: p. 5) describes, is ideal for civil society, it is unattainable in many cases, and governments may aim to extend public resources and create opportunities for civil society for political benefits (Rosenblum and Lesch: 2011: p. 289).

IPP has been more intensely practised by FBOs since the beginning of the 2000s. The JDP government formed a dyadic alliance with certain groups in civil society, and FBOs play an intermediary/mediatory role. The activities of FBOs are encouraged by legal regulations and public funds and therefore increase both in the number and volume of their activities. In line with this unseen connection that emerges between the government and certain civil society actors, FBOs engage in activities within the boundaries determined for them by the government and to the extent that the government allows. The most important precondition for government support is that FBOs act in compliance with government policies.

Design of the field research with FBOs. The primary prerequisite of any study that addresses the presence of political patronage in social assistance is substantiating it. The issue is comprehensively discussed in the Ph.D. dissertation of the author, which is based on a broad field study (Arslan Köse, 2018), and therefore, referring to the earlier study in this study is sufficient. Instead, this study examines IPP by emphasizing FBOs and their relations with the JDP government and, therefore, the state. The most important contribution of the paper, perhaps, is its harmonization of qualitative research supported by a discourse analysis with in-depth interviews. The analysis of the data obtained from the in-depth interviews and a survey of the websites of the relevant institutions is used to determine whether political patronage is targeted by social assistance practices. A comparative study among the actors enables their classification in terms of where they stand on political patronage and facilitates identifying new developments within the world of the FBOs. Therefore, this research also touches upon the changing role of FBOs in Turkish politics.

The first stage of the research entails framing a definition of IPP. There is no concept that exclusively refers to the mediatory role in political patronage; therefore, a starting point can be finding the elements of political patronage in the field and matching them to FBOs, government, and the poor. These elements are then regarded as indicators, and the definition of IPP is made accordingly. The dependency/loyalty that is created as an outcome of social assistance practices turns out to be the primary indicator of IPP.

In the second stage, case selections were made with respect to how FBOs obtain the public benefit status and where they engage in social assistance. The districts where the FBOs are located mostly coincide with the municipalities that the JDP won, and this suggests a correlation if not causation.

In the next stage, open-ended semistructured questions were prepared, and in-depth interviews were conducted with the administrators of FBOs. Five meetings were planned to be conducted in five different districts. Due to the concern expressed by the FBOs, the FBOs were randomly numbered. In addition to in-depth interviews, statistical information about the amount of social assistance and surveys of the websites of the relevant FBOs were used as data for this research.

Sampling criteria. In determining the districts and the FBOs for the field study, where in-depth interviews would be conducted, a multiplicity of factors was taken into consideration. The existence of FBOs in the districts where the JDP is in power constituted one of the criteria. Both institutionalized (old) and noninstitutionalized (new) FBOs were included in the lists. To include a district in the field study, it was necessary for all the FBOs to respond positively to the request for interviews. It has also been observed that, in the interviews conducted after July 15 , 2016, coup attempt, the interviewees sometimes provided hesitant answers. Table 1 (Yerel Seçimleri, 2014; Yerel Seçim, 2019) shows the cases selected in which the JDP won the municipal elections and there is a presence of FBOs.

Some properties of these districts are relevant to this study. In the Esenler district, poverty is clearly observable, and the district was formed through internal migration. The municipal governance displays innovative approaches and engages in a pioneering social assistance practice. The Fatih district has a much lower number of poor neighborhoods compared to other districts, and its conservative and Pro-WP constituency has better economic prospects. Küçükcekmece is one of the most crowded districts of İstanbul, containing neighborhoods where extreme poverty is experienced. Residents have family structures with characteristics of a culture of poverty that may remain contingent upon aid. Pendik carries the burden of poverty because it is an "entry" location for people migrating from Anatolia to İstanbul. Ümraniye is one of the most conservative and poorest districts of İstanbul.

In the 2019 elections, the JDP had its vote share increased. In the Küçükçekmece district, the JDP lost the elections despite the increase in its percentage of votes, which may be related to an inflow of people with better economic circumstances who do not need social assistance. Another factor may be the withdrawal of support by the Mustafa İslamoğlu community from the JDP after 2015, see https://odatv.com/bir-cemaat-daha-akpye-sirtini-midonuyor-2002151200.html for details.

FBO selection criteria. To identify the active FBOs, the list of associations that provide social assistance is obtained from the report "Associations that Work for Public Benefit" published by the "Presidency of the Department of Associations," which operates under the Ministry of Internal Affairs. Then, the presence of public benefit status, community, and year criteria (Table 2) are evaluated. For this study, the organizing criteria were primarily defined by the semiofficial status that the government attributes and the incentives that it allocates.

Community criterion. In the Turkish tradition, FBOs are mostly established by a religious community. These organizations, by the nature of their job, transcend the boundaries of the community in terms of the scope of their activities, yet the founding individuals and the decision makers are mostly the notables of these communities.

Year criterion. The main examples of these associations are the Deniz Feneri Humanitarian Aid Association and the Kimse Yok $\mathrm{Mu}$ Association. In 2014, Kimse Yok Mu was closed down due to its affiliation with the Gülen Movement, which has been targeted by the JDP government and accused of terrorism. From 2014 onward, new FBOs were established that obtained the public 
benefit status. There are no studies in the literature on these new FBOs, which are, unlike the prior organizations, not yet involved in politics.

Research findings. The major findings of this study pertain to the role of FBOs in political patronage, which is termed IPP.

To conclude the research, the relations between the state and FBOs are evaluated, and the focus is placed on state support for the FBOs. The periodic differences that stem from the analyses of the interviews were considered important and put into a section on evolution since they signify the behavior of the JDP with regard to social assistance and indicate the limits of the political space that it creates for the NGOs. Another difference based on the level of institutionalization was also involved in the overall analysis.

FBO-state relations. FBO-state relations are defined on the basis of dependency, which manifests itself mostly through state incentives and government policies. The FBOs that align themselves with government policies work coherently with the latter and function to gain loyalty for the ruling party, which eventually targets winning elections.

To frame government support for FBOs and the creation of dependency, it is necessary to consider the distinction between "appointed" and "elected" officials. The most important aspect of discrimination is that "elected" officials need the vote of the people and therefore practice political patronage, while "appointed" officials are not concerned with votes and political relationships. It should also be noted that the work of FBOs is supported and facilitated by high-level elected officials in state organs, while they are subjected to a lengthy bureaucratic process by appointed officials. The situation is disclosed by the manager of FBO-4 as follows:

"We can solve the issues immediately when we work with municipalities, governorships and muhtars. The lowest level of public administration in Turkey whose authority is limited to the provision of some documents. In principle, it means solving the issues at the upper levels. Let's say that the governor gives us permission to do such an activity and facilitates the bureaucratic processes. But when it comes down to the practice of this facilitation, there are a lot of obstacles that arise from the mentality, not from the law but from the existing mindset... The basic motivation of the appointed officers is to create something that will not put them in risky situations, so they opt for procedural methods. It is very difficult for us to overcome some obstacles. In other words, we can deal with the political will but fail at lower levels of bureaucracy, that is to say, the appointed officials."

Since the FBOs play a significant role in IPP through social assistance, we need to look at FBO-state relations and scrutinize whether the FBOs are promoted by the state in terms of receiving public grants and obtaining the public benefit status, which brings many financial and other advantages. Although the FBOs are regarded as NGOs, that is, they are independent from politics, the representatives of the FBOs expressed that every organization has a political pillar. It can fairly be claimed that the most important state support for FBOs is the public benefit status. The senior FBOs that hold this status can start a campaign without permission from the governor's office. New FBOs need to operate for at least 3 years to obtain the advantages of this status. The status inspires trust among the public for the $\mathrm{FBO}$ and makes it easier for the people to make donations. The manager of FBO-2 mentions that "It is vital to get the trust of the people for the FBOs to survive... The association's donations significantly decreased after the 15 July coup attempt." Another utility provided by the public benefit status to the $\mathrm{FBO}$ is the motivation within the institution. The manager of FBO-2, which operates in a conservative district of Istanbul, touched upon the motivation factor as follows: "we started to work after we received the status. It pushed and encouraged us." This status motivates new FBOs to maintain public trust.

There are other advantages provided by being a public benefit association, such as using black plates for vehicles. The representative of FBO-4 underlines one such advantage: "Public benefit status is very good for associations. There is a public redemption aspect of getting a black plate. You appear more mature and trusted wherever you go."

Another important practice that enables the growth of FBOs is food banking, which makes it easier for FBOs to be eligible for tax exempt status. Food banking is the second most important assistance programme after monetary support; therefore, it is very important for donation collection and the survival and growth of FBOs. With the in-kind assistance provided through the food banking system, FBOs can open their own markets and distribute food from there or enable the needy to shop at these places. At the same time, this in-kind assistance increases the volume of FBOs' income and empowers their public benefit status.

The last example of the support made by the state to the FBOs is the legislative proposal on land allocation brought about by the JDP government. According to the 49th article of the relevant bill that relates to public benefit associations, public interest associations have been added to the regulation on real estate that belongs to the treasury and the value-added tax law (Birgün, 2018). If the bill is passed as proposed, FBOs will be able to use the relevant privilege.

Another method of support is the allocation of government grants. Government grants constitute an important source of funding for $\mathrm{FBO}$ projects. While senior FBOs have knowledge and experience on the issue, new FBOs lack these benefits and therefore have difficulty in obtaining grants. "I'm against the government grant," said FBO-2's representative, "there is not enough staff and information." One of the well-established FBOs argued its position on the issue of grants as follows: "We do not receive a grant from the state at our headquarters because we consider receiving a grant as dependency on the state" (FBO-4).

The Social Support Programmes (SODES) of the Provincial Development Agencies and the Ministry of Development are important sources of funding given to NGOs by the government. Disadvantaged localities, especially in the East and South East, are included in the scope of the SODES projects. Among the organizations to which the SODES projects provide grants, NGOs take second place out of second categories that receive grants, with $30 \%$ of the grants, after public institutions. According to the data of the Ministry of Finance, NGOs have been given $\sim 5$ billion Turkish Lira in the period of the JDP government. Being regarded as NGOs, FBOs received their share through their public benefit status, their legal position and grants, and grew in proportion to their support for government policies (Birgün, 2018).

This is how the government promotes and enables civil society actors who, in return, directly or indirectly promote government policies. However, government support for NGOs that are in line with the government's ideology and the hindrance of others that are not overshadows both the independence of NGOs and the principle of an egalitarian government. From the 115,410 NGOs, only 1480 work as rights and advocacy associations, which ranks 12th in terms of activity areas. On the other side, 5421 NGOs perform humanitarian aid activities with a religious identity, which ranks 6th, while 18,247 NGOs work directly to provide religious services, which ranks 3rd (T.C. İçişleri Bakanlığı, 2018). 
These numbers illustrate the incentives provided for FBOs to harmonize their activities with government policies. A more specific case of such harmonizing comes in the form of impunity. For example, ten children who were staying at a dormitory of the Ensar Foundation were sexually harassed by a teacher who was working for the foundation. The close ideological bond between the JDP government and the foundation enabled the latter to evade legal repercussions and go unpunished (BBC News, 2016).

IPP in evolution. To better understand the state-FBO relations and their role in political patronage, it is necessary to scrutinize the changes in the JDP government's approach to FBOs. A comprehensive analysis indicates that the intensity and variety of the activities of the FBOs at home and abroad change depending on government policies. The major underlying reason for this change is the flexibility of the FBOs in terms of reorienting themselves to align with government policies. The FBOs reached an important point in their domestic aid activities after the 1999 Marmara earthquake. The subsequent rise in the number of similar organizations owes a great deal to the confidence that these organizations built after the earthquake. Despite their increasing number, it would not be fair to claim that the FBOs are currently carrying out activities with the same intensity in domestic realm. A social assistance mechanism that renders them obsolete with regard to domestic assistance was recently established by the government. The representative of FBO-5 summarized the situation as follows: "Now, we are operating in Turkey as much as the government wants us to. For example, we go to schools and talk about our projects and collect donations for our projects. Apart from that, the state is very effective in the area of social welfare, leaving a limited space for NGOs in Turkey compared to the pre-2010 period. We are leaning towards projects abroad."

However, restricting the activities of FBOs in the field of domestic aid does not create a void. State-run aid activities are very effective across the country and are increasing their influence on a daily basis. It seems that after the FBOs completed their duties at the beginning of the 2000s in the realm domestic aid, the state institutions filled the existing void by learning from them. The government, in this approach, does not want to allow the formation of alternatives in the realm of social services. Another underlying reason for limiting FBO activity may have to do with preventing $\mathrm{FBOs}$ from creating political risk by becoming too influential vis-a-vis the ruling party. Of course, FBOs have been actively utilized by the government to attract the donations of people for social assistance for a period; then, they were limited according to election arithmetic. In the 5-year period before and during the year of our interview in 2017, it was observed that the FBOs were supported in their foreign activities yet restricted in their activities in Turkey. Seeing the creation of risk for the government through "challenging the state," the representative of FBO-2 shared his opinion on FBOs' political influence: "Instead of creating 10 very large associations, 100 associations should be supported. When the association grows, the budget follows suit, and the mass of people over which they have influence also grows. Then, the association starts seeing itself as a power. This is very harmful. Then, it expects respect. The government should do certain things, and yes, they do. In certain periods, the government reduces the level of some associations when they grow too strong. If 900 million USD of 1 billion is distributed among five associations, it is not fair. No specific association should grow strong enough to challenge the government. This is what has been happening recently. If all the water passes through a single pipe, it will be stronger. However, this power does not belong to anyone. People consider the power that they acquire through association management their own personal property. This is the power of donors. Power formations must be balanced. There are 10 associations in the upper league. Twenty more should be added. The system would work better. So, let us not downsize the big associations but instead grow the smaller ones." The management of such associations is a position that accumulates prestige through the gratitude of the needy and secures a place in the power structure of the government. The power that is concentrated in a few FBOs is considered to pose a danger to political authorities. This concern also has a great deal to do with the Turkish political culture, which is highly centralized and opens a limited space for nonstate actors. The above expressions clearly expose the political orientation of the FBO and position it in the context of IPP.

It has been expressed in the interviews that FBOs have been directed toward foreign campaigns by the government in recent years. The projects, which are mostly carried out in African countries, such as providing cataract surgeries, drilling water wells, and building schools and hospitals, follow the government's policies on African expansion. In the fourth period of the Turkey-Africa Partnership, Turkey-Africa relations have deepened and diversified. In this context, NGOs have been assigned important duties by the government and are directed abroad, especially to African countries. In addition, some Middle Eastern and Asian countries are among the countries that have been aided by the JDP government to eliminate the effects of the long war. FBO-4 has always been an FBO with an intensive overseas presence since its very establishment and declares that $70 \%$ of its activities are currently outside Turkey. Limiting the space for FBOs may also be related to the slow and fragile economic growth and deteriorating democracy after 2011 (Öniș, 2015: p. 24), which made the government opt to directly distribute social assistance.

The comparison of institutionalized (vintage) and noninstitutionalized (new) FBOs. A comparative view of the vintage and new FBOs helps us understand the evolution of IPP. The division between new and vintage FBOs is expressed by Göçmen Yeginoğlu (2010: p. 153) as a characteristic stemming from the foundation stories of the associations. It is necessary to see their differences in terms of experience, performance, and legal status for the purposes of this study. Deniz Feneri Association and İHH, for example, can be defined as vintage or senior FBOs as opposed to the new FBOs that appeared after 2013 and received public benefit status. What Göçmen describes as new are regarded as vintage or senior in this study to distinguish them from the FBOs that were founded after 2013. It is even possible to observe in the present conditions that there is a trend of returning to an older, noninstitutional, informal form among the religious communities. This trend falls into the framework of the new FBOs in this study. Their affiliations with religious communities have caused these new FBOs to have a weak secular nature. While some FBOs prefer to express this link publicly, some prefer to keep it private. FBO-2, for example, acknowledges that "There is also the love of those who love Cübbeli Ahmet Hodja" [expressing the affiliation with a religious community and referring to its power. Vintage FBOs maintained greater distance from particular religious communities compared to the new FBOs. However, one needs to recognize that both the old and new FBOs are motivated by religion. The secular domination of the time of their establishment seems to have influenced the public stance of the vintage FBOs so that they reserved their affiliations with founding religious communities]. It is possible to observe religious concepts and elements in the missions that are carried out by the new FBOs. Helping Muslims in need and making a kind of spiritual investment for the afterlife is frequently expressed. The following 
position expressed during the interviews conducted for this study exemplifies this approach: "Getting the inspiration from our past, we aim to reach oppressed and victimized Muslims wherever they are and heal their wounds. It is not only about serving them in this life but also about helping them win the afterlife" (FBO-2).

Similarly, "in order to ensure that justice and charity are dominant in the world and by prioritizing Muslims through the consciousness of religious brotherhood, we aim to help the needy and oppressed people in material and spiritual ways" (FBO-1). However, there is no such religious emphasis on the missions and mission statements of vintage FBOs. "Good deeds" are expressed through work on secular concepts. Deniz Feneri Association's mission statement frames its perspective as "pioneering and guiding the formation and development of a spirit of mutual aid, observing the expectations of all interested parties and constantly improving our quality management system to reach the last person in need of assistance on earth" (Deniz Feneri 2018). İHH expresses itself in a more comprehensive way: "...to do all the necessary work to ensure that basic rights and freedoms of all people are not violated and to prevent all kinds of policies and activities that cause people to need humanitarian assistance" (İHH, 2018). Such secular-leaning attitudes have been further established through institutionalization. The new FBOs lack the experience to form such language. In addition, conservatives were politically dominant during the formative years of these FBOs, and therefore, they did not need to redress their perspective on a secular basis.

The distinction on the basis of secular and conservative leanings manifests itself in the employment policies of FBOs. It would be fair to say that while female workers are present in equal numbers as male workers in existing FBOs, the same is not true of the new FBOs. In the new FBOs, women are more commonly employed in public relations departments and perform researchoriented duties rather than field tasks. While men's clothing is mostly modern in existing FBOs, it was observed to be more traditional and religious in the new FBOs, such as the wearing of the shalwar, a long white shirt, and skullcap. This fact may also be related to the increasing visibility of religious elements in the public sphere after the 2011 elections.

The experience of the old FBOs includes obtaining the skills necessary to access state resources. The new FBOs do not have such skills and consider the situation discriminatory in favor of old FBOs. In the field research, it has been identified that the new FBOs refer to the old FBOs as the "upper league," emphasizing the advantages and power that the old FBOs wield: "There is the upper league, I mean, the associations like Deniz Feneri, AFAD and Red Crescent. We are in a lower league. The associations in the upper league open campaigns without permission, but the new ones have to get permission. We do not have that privilege yet, and therefore, we are in a different league in the eyes of the state" (FBO-2). The new FBOs are disturbed by the unfair conditions of competition, which favor the old FBOs. This disturbance also facilitates the understanding that the institutionalized FBOs cause a threat to the very existence of the state. An example is offered with regard to the failed coup attempt: "The big FBOs see the citizens in the way that the state officials do. The Gülenists Terror Organization (FETÖ) became public with their claims of carrying out social services but attempted to seize political power and rule the country. We should not go astray from our goal. I am against the political and commercial involvement of the communities and charities. You cannot engage in trade or politics through social assistance organizations. This is against the spirit of donation and social assistance. Personal interest and greed gets in the way" (FBO-2).

On the other hand, the new (noninstitutionalized) FBOs also want to grow as the older FBOs did because the increase in the amount of donations is directly proportional to growth. It is frequently stated that the old FBOs are closer to the state and that the state favors them. The new FBOs that indicate the need for state support appear to be weak in their cooperation with the state. The reason for this situation should be sought not in an ideological difference but in the level of professional performance that the new FBOs offer. For example, these FBOs do not have expert staff with the necessary skills in writing proposals for grant projects. This failure limits their capacity to harvest and utilize state resources. While these FBOs want to receive public resources, they may not even be aware of the deficit that they have in terms of the necessary expertize and know-how. These FBOs say, "the authorities want projects from us. Let us approve the project that you have, they say. Why do we bring you the project? The state should bring the project on which we can work together." In fact, when the state says "Let's approve the project," it means, "We, as the public authority, support you as a new FBO, but you have to write a project for us to transfer the appropriate state resources to you" (FBO-1-2). The old FBOs, however, have knowledge and experience in project writing; therefore, they can easily use government resources. When these FBOs do not use state resources, the reason is mostly related to avoiding dependence on the state. The new FBOs also do not have quality process management mechanisms, and they fail to quickly respond to the demands of the needy, which sometimes takes three months.

Finally, the institutionalized FBOs filled the voids created by the incompetency of the state after the 1999 earthquake, carrying the prestige and brand value of being in the frontline at tough times. The noninstitutionalized FBOs do not have such brand value since they have not yet proven themselves in difficult times. However, each major old FBO is matched with a political event: the Deniz Feneri Association is associated with the corruption case in Germany, the İHH with the Mavi Marmara incident, and the Kimse Yok Mu with the Gülenists, which tarnishes their image in the public perception. Deniz Feneri has never reached the donation level that it previously had after the Germany incident in 2007, although the overall donations that FBOs receive increased recently. İHH seems to have caught up with its previous donation level and continues without a decrease. The Mavi Marmara incident indicated clear political engagement but also enabled it to win new supporters. Although the Kimse Yok $\mathrm{Mu}$ Association has been excluded from this study because it was shut down due to its alleged terrorist affiliation, it needs to be referred to here since it had been recognized as one of the largest vintage FBOs in many studies (Göçmen, 2014). The negative experiences of the institutionalized FBOs, which decreased the public trust that they enjoyed, also decreased the donation levels for the noninstitutionalized FBOs. In other words, the diminished image of the large institutionalized FBOs has also exacerbated the overall public trust in and therefore the donations for the new FBOs.

The institutionalized FBOs focus on overseas activities, as mentioned above, due to the JDP government's policies. Noninstitutionalized FBOs also work abroad but at a lower level than institutionalized FBOs. The institutionalized FBOs have gained professional abilities and become more secular in time to gain broader public and global access. These organizations also acquired corporate skills in the field of civil society to obtain public and civilian resources. A striking feature of these organizations is that the institutionalized FBOs have been involved in politics in the past and need to improve their image to reach the donation level of their golden age. In other words, FBOs' relations with the state became more visible in the context of IPP, and this publicity confused their image of autonomy and independence. Table 3 compares the noninstitutionalized and the institutionalized $\mathrm{FBOs}$ across various parameters 


\begin{tabular}{|c|c|c|}
\hline Attributes & $\begin{array}{l}\text { Institutionalized } \\
\text { FBO }\end{array}$ & Noninstitutionalized FBC \\
\hline $\begin{array}{l}\text { Period of obtaining } \\
\text { public benefit status }\end{array}$ & Early 2000s & After 2013 \\
\hline Secularization & High & Low \\
\hline Professionalization & High & Low \\
\hline $\begin{array}{l}\text { Relationship with the } \\
\text { government }\end{array}$ & High & Low \\
\hline $\begin{array}{l}\text { Benefitting from state } \\
\text { resources }\end{array}$ & High & Low \\
\hline $\begin{array}{l}\text { Cooperation with the } \\
\text { government }\end{array}$ & High & Low \\
\hline $\begin{array}{l}\text { Affiliation with religious } \\
\text { communities }\end{array}$ & Low & High \\
\hline $\begin{array}{l}\text { Domestic social } \\
\text { assistance }\end{array}$ & Low & Low \\
\hline $\begin{array}{l}\text { International social } \\
\text { assistance }\end{array}$ & High & High \\
\hline Involvement in politics & High & Low \\
\hline
\end{tabular}

The variety of social assistance and loyalty in IPP. Loyalty is not as important an indicator of IPP as dependency is; however, because of its significant overlap with dependency, it is relevant in this study. As a concept, loyalty includes consent alongside dependency and has a more established nature than dependency. Social assistance programmes can mainly be divided into cash and in-kind transfers by FBOs. While public social assistance institutions transfer cash to people in need, FBOs and municipalities prefer to operate a multiplicity of social aid programmes. It is a fruitful environment to reach out and communicate directly with the people who are in need. The variety of social assistance may create loyalty to the organization and therefore to the government, which has the same ideology. There is no doubt that "providing cash is the most favorable form of social assistance among those people," as the representative of FBO-3 said. The multiplicity allows people who do not meet the criteria for one assistance type apply for another. For example, the holy month of Muslims, Ramadan, is an important occasion for this type of interaction, and most of the time, it is utilized as much as possible: "The benefits get better in Ramadan. Iftar dinners that are delivered to homes, offered in tents, suhoor and food packages are more frequent," said all the representatives of the interviewed FBOs. The variety of social assistance manifested itself in the aftermath of the attempted coup of July 15, 2016, that is, the FBOs became more public to show that they can be trusted in terms of not being affiliated with any alleged terror groups. This approach might be assessed as an attempt to survive in the state of emergency declared by the government after the coup attempt, which was less-than-friendly for civic initiatives. Food packages, water supply, etc., were used to gain the trust of the people.

Finally, the variety of FBO projects provides access to diverse groups in society. To illustrate this point, Deniz Feneri Derneği has the "Kindness School" project in collaboration with the Turkish Ministry of Education, which is mostly for Islamic schools operated by the state (Deniz Feneri Derneği, 2018). Another existing and pioneering $\mathrm{FBO}, \dot{\mathrm{I}} \mathrm{HH}$, declares its mission to be improving solidarity, brotherhood, and kindness in Turkey (İHH, 2018). Some project names that suggest this diversity are "What are we doing when our neighbors are cold?" (Yardimeli, 2017), "The Wheelchair Project" (Valide, 2018), and "Social and Cultural Aids" (Beşir Derneği, 2013). Thus, these projects help sustain religion-conservative values, which are also manifested in JDP's political stance and contribute to IPP.

\section{Conclusion}

A new understanding of political patronage in Turkey that is based on creating dependency through social assistance programmes is analyzed in a broad study (Arslan Köse, 2018). The study argues that the JDP government prepared the conditions for sustainable dependency. Keeping the minimum wage low and maintaining a lack of enthusiasm for reducing the unemployment rate provide an adequate environment to make people depend on the government through social assistance programmes in a sustainable manner. Social benefits given from public sources increased to unprecedented levels (Çelik, 2010; Buğra, 2011; Yıldırım, 2013; Koray and Çelik, 2015) and have been utilized to secure election victories for the JDP government.

FBOs seem to function by consolidating the authority of the government in a way that is reminiscent of the Gramscian perspective on the instrumentalization of civil society. The significance of this paper is that it brings together a discussion on FBOs (religion) and political patronage implementations in social assistance programmes (poverty) to understand and examine the role played by FBOs in the concept of IPP. To scrutinize these roles, the examination of the relationship between the state and the FBOs in the social assistance programmes is of key importance. The relationship can be observed in several spheres, such as governmental incentives (the provision of grants, public benefit status, land, etc.), as dependency indicators. Furthermore, the facilitation of FBOs' application of these incentives by political actors, proliferation of FBOs and increase in their activities, especially in the first decade of the JDP government, play major roles in this relationship, indicating the strong and mutual relationship between the government/state ${ }^{1}$ and the FBOs.

It would be less-than-fair to claim that FBOs are used only for political patronage purposes. However, in the first decade of the JDP period, FBOs started playing more centralized roles in governmental social assistance programmes using a variety of governmental incentives. However, after the first decade, the FBOs started complaining that they were given a "limited environment in which to perform in the domestic realm" (FBO-4). For this reason, these organizations have turned toward foreign countries, especially in Africa. The JDP government has been performing better in using public resources than the other (civic) social assistance protagonists.

Another contribution of this paper is the comparison of FBOs as actors in IPP in the social assistance field. These organizations were classified into two major groups: institutionalized and noninstitutionalized. While the noninstitutionalized FBOs have publicly acknowledged affiliations with religious communities, the institutionalized FBOs seem to have transformed into secular organizational bodies over time. The institutionalized FBOs have also been involved in politics. Having supported the FBOs that engage in activities in line with their policies, the JDP government does not provide any support for critical NGOs with regard to rights advocacy initiatives. The state resources have been utilized for creating dependency on government assistance and therefore for patronage purposes in an indirect way.

As a result, this study defines FBOs in terms of their political affiliations, discloses the relationship beyond charity work, and reveals the dependency behind seemingly autonomous civic initiatives. FBOs proliferated during the JDP rule, and they survived as long as they remained within the boundaries set by the government.

\section{Data availability}

Data sharing is not applicable to this paper as no datasets were generated or analyzed. 
Received: 8 February 2019 Accepted: 25 June 2019

Published online: 06 August 2019

\section{Notes}

1 Recently, the government and the state have become rather intertwined concepts in both public language and the academic literature in Turkey.

\section{References}

Ahmad F (1993) The making of modern Turkey. Routledge, London

Althusser L (2014) On the reproduction of capitalism: ideology and ideological state apparatuses. Verso, London. G. M. Goshgarian (trans.)

Arslan Köse S (2018) Social assistance as an instrument of political patronage in Turkey. Ph.D. Thesis, Yeditepe University, Istanbul, (Unpublished)

Ayata AG (1994) Roots and trends of clientalism in Turkey. In: Roniger L and Ayata AG (eds) Democracy, clientalism and civil society. Lynne Rienner Publisher, London, p 49-64

Bakırezer G and Demirer Y (2013). In: Uzgel İ, Duru B (eds) AK Parti'nin Sosyal Siyaseti. AKP Kitabı: Bir Dönüşümün Bilançosu (2002-2009). Phoenix, Ankara, p 153-178

Baytal Y (2012) Atatürk Döneminde Sosyal Yardım Faaliyetleri: 1923-1938. Atatürk Araștırma Merkezi, Ankara

BBC News (2016) Karaman'da Cocuklara Taciz İddiaları: Ne Oldu, Ne Olacak? BBC News Türkçe. https://www.bbc.com/turkce/haberler/2016/03/ 160328 karaman dava. Accessed 5 Mar 2018

Beşir Derneği (2013) Sosyal ve kültürel yardımlar. Beşir Derneği. https://www.besir. org.tr/Detay/TR\%7C\%7Csosyal-ve-kulturel-yardimlar-67.html. Accessed 10 Feb 2018

Birnir J (2009) Ethnicity and electoral politics. Cambridge University Press, Cambridge

Birgün (2018) Birgün Güncel. Birgün. https://www.birgun.net/haberdetay/ vakiflardan-sonra-derneklere-de-kiyak-203170.html. Accessed 6 Feb 2018

Bora T (2009) Yoksullukla Mücadele Stratejileri Üzerine: Sadaka, Sosyal Yardım, Dayanışma, Örgütlenme. Birikim Derg 241:19-23

Boratav K (2003) Türkiye İktisat Tarihi: 1908-2002. İmge Kitabevi, Ankara

Brun DA (2014) Evaluating political clientelism. In: Brun DA, Diamond L (eds) Clientelism, social policy and the quality of democracy. Johns Hopkins University Press, Baltimore, p 1-14

Buğra A (2011) AKP’nin Seçim Başarısının Garipliği ve Anlaşılabilirliği. Bianet. https://bianet.org/biamag/bianet/130856-akp-nin-secimbasarisinin-garipligive-anlasilabilirligi. Accessed 24 Apr 2018

Buğra A, Keyder Ç (2006) Sosyal Politika Yazıları. İletişim, İstanbul

Burgess R, Jedwab R, Miguel E, Morjaria A, Miquel GP (2015) The Value of democracy: evidence from road building in Kenya. Am Econ Rev 105 (6):1817-1851

Chandra K (2004) Why ethnic parties succeed: patronage and ethnic head counts in India. Cambridge University Press, Cambridge

Clarke G (2008) Development, civil society and faith-based organisations organisations: bridging the sacred and the secular. In: International political economy series. Palgrave Macmillian, London

Çarkoğlu A, Kalaycıoğlu E (2009) The rising tide of conservatism. Palgrave, London

Çelik A (2010) AKP'nin Muhazakar Sosyal Politikası: Hak Yerine Yardım, Yükümlülük Yerine Hayırseverlik. Siyasal 42:63-81

Deniz Feneri Derneği (2018) İyilik Okulu. Deniz Feneri Derneği. https://www. denizfeneri.org.tr/haberler/istanbul-milli-egitim-mudurlugu-ile-deniz-feneriiyilik-okulu-protokolunu-imzaladi_3889/. Accessed 20 Feb 2018

Diamond L (1994) Rethinking civil society: toward democratic consolidation. J Democr 5(3):4-17

Dinçşahin Sุ (2012) A symptomatic analysis of the JDP's populism in Turkey, 20072010. Gov Oppos 47:618-640

Ferrera M (1996) The southern model of welfare in social Europe. J Eur Soc Policy 6(1):17-37

Ferris E (2005) Faith-based and secular humanitarian organizations. Int Rev Red Cross 87(858):311-325

Frank R, Rainer I (2012) Does the leader's ethnicity matter? Ethnic favoritism, education and health in Sub-Saharan Africa. Am Political Sci Rev 106 (2):294-325

Freedman A (1994) Patronage: an American tradition. Nelson-Hall, Chicago

Ginio E (2003) Living on the margins of charity: coping with poverty in an Ottoman provincial city. In: Bonner M, Ener M, Singer A (eds) Poverty and charity in Middle Eastern Contexts. State University of New York Press, New York, p 165-185

Gough I (1996) Social assistance in Southern Europe. South Eur Soc Politcs 1 (1):1-23
Göçmen Yeginoğlu İ (2010) The Politics of Religiously Motivated Welfare Provision. Unpublished doctoral thesis. Universitäts- und Stadtbibliothek Köln, Germany

Göçmen İ (2014) Religion, politics and social assistance in Turkey: the rise of religiously motivated associations. J Eur Social Policy, 24(1):92-103

Gramsci A (1971) State and Civil Society. Lawrence and Wishart Ltd., UK

Gramsci A (1999) Selection from the prison notebooks. Elecbook, London

Heper M (1997) Islam and democracy in Turkey: toward a reconciliation? Middle East J 51(1):32-45

Heper M (2015) Türkiye'de Devlet Geleneği. Doğu Batı Yayınları, Ankara

Heper M, Keyman F (2006) Double-faced state: political patronage and the consolidation of democracy in Turkey. Middle East Stud 3(4):259-277

İHH (2018) Humanitarian Relief. İHH. https://www.ihh.org.tr/en/humanitarianrelief

Jawad R (2012) From wellbeing to ways of being: religion and faith-based in the UK. Policy Press, Bristol

Jawad R, Cakar BY (2010) Religion and social policy in the ME: the (re)constitution of an old-new partnership. Soc Policy Adm 44(6):658-672

Isaksson AS, Bigsten A (2014) Clientelism and ethnic divisions. Working papers in economics no 598, University of Gothenburg, Gothenburg

Kalaycıoğlu E (2001) Turkish democracy: patronage versus governance. Turk Stud 2:54-70

Kalaycıŏglu E (2007) Politics of conservatism in Turkey. Turk Stud 8(2):233-252

Kalfa TA (2015) Dilenciler: Türkiye'de Yoksulluk ve Dilenme Kültürü. İletişim Yayınları, İstanbul

Karatay A (2010) Türkiye'de Yoksulluk Yoksullukta Değişsmeler ve Sosyal Hizmetlerin Artan Önemi. In: Semerci P (ed.) İnsan Hakları İhlali Olarak Yoksulluk. Bilgi Üniversitesi Yayınları, İstanbul

Kaya A (2015) Islamisation of Turkey under the AKP Rule: empowering family, faith and charity. South Eur Soc Politics 20(1):47-69

Keyman EF (2010) Modernization, globalization and democratization. Constellations 17(2):312-327

Koray M (2012) Sosyal Politika. İmge Kitabevi, İstanbul

Koray M, Çelik A (2015) Himmet, Fitrat, Piyasa: AKP Dönemi'nde Sosyal Politika. İletisim Yayınları, İstanbul

Köse AH, Bahçe SB (2012). In: Uzgel İ, Duru B (eds) Hayırsever Devletin Yükselişi: AKP Yönetiminde Gelir Dağılımı ve Yoksulluk. AKP Kitabı: Bir Dönüşümün Bilançosu (2002-2009). Phoenix, Ankara, p 492-509

Kudamatsu M (2009) Ethnic favoritism: micro evidence from Guinea. Stockholm University, Sweden

Kurtoğlu A (2012) Siyasal Örgütler ve Sivil Toplum Örgütleri Bağlamında Hemsehrilik ve Kollamacilık. Ankara Üniversitesi, Ankara. 67(1):141-169

Landé C H (1977) The dyadic basis of clientelism. In: Schmidt S W, Scott J C, Landé C H, and Gusty L (eds) Friends, Followers and Factions: A Reader in Political Clientelism. University of California, Berkeley and Los Angeles, XIII-XXXVII

Lewis B (1968) The emergence of modern Turkey. Oxford University Press, London

Makal A (1997) Osmanlı İmparatorluğu’nda Çalışma İlișkileri: 1850-1920. İmge Kitabevi, Ankara

Mardin Ş (1973) Center-periphery relations: a key to Turkish politics? Post-Tradit Soc 102:169-190

Milliyet E (2016) Paket paket sosyal yardım devreye girdi. Kılıç, C. http://www. milliyet.com.tr/yazarlar/cem-kilic/paket-paket-sosyal-yardim-devreye-girdi2204819. Accessed 06 Feb 2018

Moynihan DP, Wilson JO (1964) Patronage in New York state. 1955-1959. Am Political Sci Rev 58(2):286-301

Nichter SC (2010) Politics and poverty: electoral clientelism in Latin America. Doctoral thesis on political science, University of California, California, (Unpublished)

Ocaklı F (2017) Islamist performance in Turkey. South Eur Soc Politics 22 (1):61-80

Önis Z (2015) Monopolising the centre: the akp and the uncertain path of Turkish democracy. Int Spect 50(2):22-41

Robinson JA, Verdier T (2013) The political economy of clientelism. Scand J Econ 115(2):260-291

Rosenblum NL, Lesch CH (2011) Civil society and government. In ME (ed) Civil society. Oxford University Press, Oxford, p 285-297

Sarıbay AY (1992) Siyasal Sosyoloji: Bir Çözümleme Çerçevesi. Gündoğan oyoyYayınları, Ankara

Sayarı S (1977) Political patronage in Turkey. In: Gellner E, Waterbury J (eds) Patrons and clients in Mediterranean societies. Duckworth, London, p $103-130$

Sayarı S (2011) Clientalism and patronage in Turkish politics. In: Toprak B, BF (eds) The post modern abyss and the new politics of Islam. Bilgi University, İstanbul, p 81-94

Scott JC (1972) Patron-client politics and political change in Southeast Asia. Am Political Sci Rev 66(1):91-113 
Sider RJ, Unruh HR (2004) Typology of religious characteristics of social services and educational organizations and programs. Non-Profit Volunt Sect Quartley 33(1):109-134

Stokes S (2007) Political clientelism. In: Stokes S, Boix C (eds) The Oxford handbook of comparative politics. Oxford University Press, Oxford

Sunar İ (1990) Populism and patronage. II Politico 60(4):745-757

Swart I, Rocher H, Green S, Erasmus J (eds) (2010) Religion and social development in post Apartheid South Africa. Sun Press, Stellenbosch

Talas C (1980) Ekonomik Sistemler. S Yayınları, Ankara

T.C. Dışişleri Bakanlığı (2018) Türkiye Afrika İlişkileri. T.C. Dışişleri Bakanlığı. http://www.mfa.gov.tr/turkiye-afrika-iliskileri.tr.mfa. Accessed 14 Feb 2018

T.C. İçişleri Bakanlığı (2018) Derneklerin Faaliyet Alanına Göre Dağılımı. T.C. İçişleri Bakanlığı Sivil Toplumla İlişkiler Genel Müdürlüğü. https://www. dernekler.gov.tr/tr/AnasayfaLinkler/derneklerin-faaliyet-alanina-gore.aspx. Accessed 15 Feb 2018

Yardımeli (2017) Komşusu Açken Tok Yatanlar. Yardımeli: Uluslararası İnsani Yardım Derneği. https://yardimeli.org.tr/tr/news/19081/komsusu-acken-tokyatanlar. Accessed 10 Feb 2018

Yerel Seçimleri (2014) Seçim.Haberler.Com. https://secim.haberler.com/2014/. Accessed 1 Aug 2018

Yerel Seçim (2019) NTV. http://secim.ntv.com.tr/. Accessed 30 Apr 2019

Yıldırım D (2013) AKP ve Neoliberal Popülizm. In: Uzgel İ, Duru B (eds) AKP Kitabı: Bir Dönüșümün Bilançosu (2002-2009). Phoenix, Ankara, p 66-107

Valide (2018) Valide İnsani Yardım Derneği. https://valide.org.tr/bagisyap/engelliarabasi_16.html. Accessed 10 Feb 2018

Wantchekon L (2003) Clientelism and voting behaviour: evidence from a field experiment in Benin. World Politics 55:399-422

Weingrod A (1968) Patrons, patronage, and political parties. Comp Stud Soc Hist 10(4):377-400

\section{Additional information}

Competing interests: The author declares no competing interests.

Reprints and permission information is available online at http://www.nature.com/ reprints

Publisher's note: Springer Nature remains neutral with regard to jurisdictional claims in published maps and institutional affiliations.

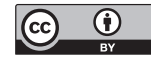

Open Access This article is licensed under a Creative Commons Attribution 4.0 International License, which permits use, sharing, adaptation, distribution and reproduction in any medium or format, as long as you give appropriate credit to the original author(s) and the source, provide a link to the Creative Commons license, and indicate if changes were made. The images or other third party material in this article are included in the article's Creative Commons license, unless indicated otherwise in a credit line to the material. If material is not included in the article's Creative Commons license and your intended use is not permitted by statutory regulation or exceeds the permitted use, you will need to obtain permission directly from the copyright holder. To view a copy of this license, visit http://creativecommons.org/ licenses/by/4.0/.

(C) The Author(s) 2019 